\title{
IMPLEMENTASI GLPI (GESTIONNAIRE LIBRE DE PARC INFORMATIQUE) UNTUK LAYANAN IT, MANAJEMEN ASET DAN RESERVASI ASET PADA PT XYZ
}

\author{
Dwika Nur Ridlo Robby \\ Program Studi Teknik Multimedia dan Jaringan \\ Jurusan Teknik Informatika dan Komputer \\ Politeknik Negeri Jakarta \\ dwika.nurridlorobby.tik16@mhsw.pnj.ac.id
}

\begin{abstract}
The purpose of this research is to implement IT asset management and tools using open source software. The software used is GLPI (Gestionnaire Libre de Parc Informatique), an Asset and IT management system package that provides the Service Desk, License Tracking and Software Audit features. GLPI is a free asset and IT management software, a software for asset management, with an additional interface for filing requests and also for reporting related to IT technicians who write in php language and are distributed under the GPL license (General Public License).
\end{abstract}

Keywords: Asset and IT management, GLPI, Service Desk.

Abstrak - Tujuan penelitian ini untuk mengimplementasikan tools aset dan manajemen IT dengan menggunakan open source software. Software yang digunakan adalah GLPI (Gestionnaire Libre de Parc Informatique), sebuah paket sistem Aset dan manajemen IT yang menyediakan fitur Service Desk, License Tracking dan Software Auditing. GLPI merupakan free asset and IT management software, suatu perangkat lunak untuk manajemen aset, dengan tambahan antar muka untuk pengajuan permintaan dan juga untuk pelaporan insiden kepada teknisi TI yang di tulis dalam bahasa php dan di distribusikan di bawah lisensi GPL (General Public License).

Kata kunci: Aset dan manajemen IT, GLPI, Service Desk.

\section{Pendahuluan}

PT. XYZ merupakan sebuah perusahaan yang didedikasikan untuk fokus pada aspek Teknik dan Operasional di bidang gas. PT. XYZ mempunyai 16 kantor area. Divisi IKT (Informasi Komunikasi dan Teknologi) sebagai salah satu divisi yang bertanggung jawab untuk mengelola segala macam jenis infrastruktur IT, menyediakan layanan IT dan mengelola inventaris terhadap seluruh aset yang ada baik di kantor pusat maupun di kantor area.

Pada kantor pusat PT. XYZ, terdapat berbagai macam perangkat lunak dan perangkat keras yang berperan untuk mendukung proses operasional kantor. Invetarisir seluruh aset IT masih menggunakan sistem manual. Pencatatan secara manual juga tidak akurat dan tidak praktis serta mempunyai resiko yang lebih besar.

Begitu juga untuk permintaan layanan IT yang masih menggunakan formulir kertas. Cara tersebut menyebabkan banyaknya kertas yang menumpuk sehingga terkadang ada formulir yang hilang. Selain itu divisi IKT juga menyediakan peminjaman aset IT untuk divisi lainnya. Oleh karena itu dibutuhkan suatu software yang dapat mengelola peminjaman aset IT tersebut.
Untuk mengatasi masalah tersebut, divisi IKT mempunyai suatu proyek untuk instalasi tools aset dan manajemen IT dengan menggunakan open source software. Software yang digunakan adalah GLPI (Gestionnaire Libre de Parc Informatique), sebuah paket sistem Aset dan manajemen IT yang menyediakan fitur Service Desk, License Tracking dan Software Auditing. Dengan diterapkannya software baru ini diharapkan kedepannya dapat mempermudah pekerjaan administrator sistem dalam mengelola aset serta dapat mengoptimalisasi layanan IT.

\section{Tinjauan Pustaka}

2.1 IT Asset Management

IT Asset Management atau Manajemen aset IT merupakan suatu praktek bisnis yang melibatkan serta menjaga suatu aset IT dalam hal inventaris akurat, informasi lisensi, pemeliharaan, dan perlindungan aset perangkat keras dan perangkat lunak digunakan oleh suatu lembaga. (Nursikuwagus \& Juliana, 2016).

Siklus hidup aset menjadi tiga tahap. Tahap yang pertama adalah pengadaan (procurement). Dimana ketika suatu aset diperoleh kemudian aset itu memasuki sistem manajemen aset dan mulai dikelola. Tahap yang kedua adalah penyebaran (deployment). Ketika suatu aset digunakan, sistem harus diperbarui dengan data yang relevan, seperti 
data lokasi, pihak yang bertanggung jawab, konfigurasi, garansi dan data lain yang akan berguna dalam mengelola aset.

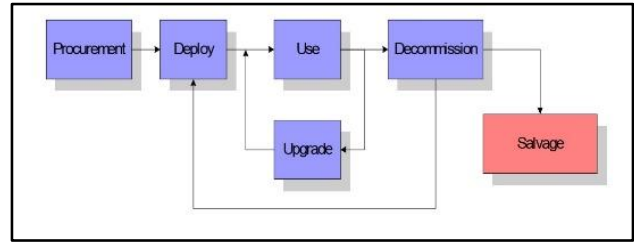

Gambar 2.1 Linear Sequential Model

Tahap yang ketiga adalah penggunaan (usage). Dari waktu ke waktu, aset tersebut mungkin ditingkatkan (upgraded) dalam beberapa cara. Versi perangkat lunak dapat berubah atau hard drive baru dapat ditambahkan. Ketika hal tersebut terjadi, konfigurasi untuk aset harus diperbarui.

Ketika suatu aset tidak lagi digunakan, kemudian dinonaktifkan (decommissioned). Aset yang dinonaktifkan mungkin masih berguna untuk organisasi, dalam hal ini dapat didistribusikan. Jika tidak, aset tersebut mungkin masih memiliki beberapa nilai sisa (salvage) dan sistem manajemen aset harus melacak aset tersebut sampai selesai. (Windley \& Ph, 2002)

Pengelolaan aset yang baik dapat memperpanjang umur aset dalam perusahaan. Pemeliharaan aset dengan baik dapat menjadikan aset tahan lama sehingga masa produksinya dapat lebih lama dan memberikan keuntungan bagi perusahaan. (Octaviyanti \& Andry, 2018)

\subsection{IT Service Management}

IT Service Management adalah sebuah sistem manajemen yang tujuannya menyelaraskan penyampaian layanan teknologi dengan memaksimalkan layananan kepada pelanggan atau pengguna layanan. IT Service Management mengarah pada seluruh kegiatan yang dilakukan oleh organisasi untuk merencanakan, mendesain, memberikan, mengoperasikan, dan mengendalikan layanan TI pada pelanggan. Selain itu dengan adanya manajemen ini dapat mengurangi pengeluaran biaya yang tinggi dengan menjaga dan mengatur persediaan.

Apabila suatu organisasi tidak mengelola Layanan TI dengan tepat dan baik kemungkinan organisasi tersebut tidak dapat memastikan layanan-layanan TI yang dibutuhkan akan tersedia ketika dibutuhkan, dan apabila ini terjadi, layanan yang diberikan oleh sebuah Departemen TI untuk mendukung proses bisnis akan menjadi kurang efektif dan efisien. Sehingga akibatnya Departemen TI tidak dapat memenuhi atau mendukung tujuan keseluruhan organisasi atau perusahaan lain. (Bella Nemesias, 2018, 28 November 2019)

Umumnya proses ITSM ada tiga, yaitu sebagai berikut (Stephen Mann, 2017, 1 Desember 2019): a. Incident management - menangani permintaan bantuan dengan masalah IT melalui help desk atau service desk.

b. Request Fulfillment - menangani permintaan, penyediaan, layanan IT baru melalui help desk atau service desk.

c. Change management - manajemen IT dan perubahan bisnis yang efektif.

\subsection{GLPI (Gestionnaire Libre de Parc Informatiquea)} GLPI merupakan singkatan dari Gestionnaire Libre de Parc Informatiquea yang dalam bahasa inggris berarti free asset and IT management software adalah merupakan suatu perangkat lunak untuk manajemen aset, dengan tambahan antar muka untuk pengajuan permintaan dan juga untuk pelaporan insiden kepada teknisi TI yang merupakan software open source yang di tulis dalam bahasa php dan di distribusikan di bawah lisensi GPL (General Public License). Dimana setiap orang dapat bebas menjalankan, memodifikasi serta mengembangkan sesuai dengan kebutuhan yang membuat fungsi seorang administrator menjadi lebih mudah.

Fitur-fitur yang disediakan oleh GLPI adalah sebagai berikut:

a. Assets Management.

b. Data inventori untuk komputer, printer, dan perangkatperangkat IT lainnya dengan menggunakan tool semacam OCS Inventory atau FusionInventory.

c. Manajemen daur-hidup perlengkapan

d. Reservasi penggunaan aset

e. Manajemen insiden, permintaan, masalah dan perubahan.

f. Pembuatan tiket melalui email, dengan antar muka yang berbeda antara teknisi dengan user

g. Manajemen tiket bantuan (pendelegasian, penjadwalan, solusi, dan sebagainya)

h. GLPI juga mendukung banyak plugin lainnya yang dapat menambah fitur selain yang disebutkan diatas.

Dari fitur-fitur itu saja dapat dibilang cukup meng-cover semua kebutuhan operasional departemen IT. Jadi tidak perlu lagi menggunakan tools yang terpisah. (Welly Rosadi, 2017, 27 November 2019)

\subsection{Virtual Box}

VirtualBox merupakan perangkat lunak virtualisasi, yang dapat digunakan untuk mengeksekusi sistem operasi tambahan di dalam sistem operasi utama. Sebagai contoh, jika seseorang mempunyai sistem operasi yang terpasang di komputernya, maka seseorang tersebut dapat pula menjalankan sistem operasi lain yang di inginkan di dalam sistem operasi MS Windows. Fungsi ini sangat penting jika seseorang ingin melakukan uji coba dan simulasi instalasi suatu sistem tanpa harus kehilangan sistem yang ada. (Desmira et al., 2017) 


\subsection{Linux Ubuntu}

Merupakan sistem operasi yang diciptakan oleh Linus Trovalds di bawah lisensi GPL (General Public Licensi). Distro berasal dari kata distribution yang dapat diartikan sebagai penyebaran, jika dikaitkan dengan Linux, maka adalah penyebaran paket Linux. Kelebihan Linux di antaranya, tahan terhadap serangan virus, tidak mudah crash dan hang karena window manager terpisah dengan inti dari sistem operasi, mudah didapat dengan harga terjangkau, mempunya lisensi yang sangat moderat, dapat berjalan di beberapa arsitektur komputer 32bit atau 64bit, ringan, terutama jika tanpa menggunakan GUI (Graphical User Interface). (Desmira et al., 2017)

\subsection{HTTP}

HyperText Transfer Protocol (HTTP) menjadi protokol yang paling banyak digunakan di Internet. Setiap web browser dan server saling berhubungan dan bertukar informasi menggunakan protokol ini. Dalam format yang paling dasar, ini dalah bentuk bagaimana halaman web dikomunikasikan dari web server ke browser pengguna. (Fauzy Ramdhani, 2015)

\subsection{Apache}

Apache adalah sebuah aplikasi web server. Tugas utama Apache adalah menghasilkan halaman web yang benar kepada user berdasarkan kode PHP yang dituliskan oleh pembuat web. (Sidik et al., 2015)

\subsection{MySQL}

MySQL adalah RDMS (Relational Database Management System) yang diditribusikan secara gratis dibawah licensi GPL (General Public License). MySQL sebenarnya merupakan turunan salah satu konsep utama dalam database sejak lama yaitu SQL (Structured Query Language). SQL adalah sebuah konsep pengoperasian database terutama untuk pemilihan/seleksi dan pemasukan data yang memungkinkan pengoperasian data dikerjakan dengan mudah dan secara otomatis. (Candra et al., 2015)

\subsection{PHP}

Merupakan salah satu bahasa pemograman yang berjalan dalam sebuah web server dan berfungsi sebagai pengolah data pada sebuah server. Data yang dikirim oleh user client akan diolah dan disimpan pada database web server dan dapat ditampilkan kembali apabila diakses. PHP bekerja didalam sebuah dokumen HTML (Hypertext Markup Language) untuk dapat menghasilkan isi dari sebuah halaman web sesuai permintaan. Dengan PHP, dapat merubah situs menjadi sebuah aplikasi berbasis web, tidak lagi hanya sekedar sekumpulan halaman statik, yang jarang diperbaharui. (Mubarak, 2019)

\subsection{0 phpMyAdmin}

phpMyAdmin adalah sebuah software gratis berbasis scripting language PHP yang bertujuan untuk memudahkan dalam mengelola database MySQL. Tanpa phpMyAdmin, diperlukan terminal untuk mengelola database. (Dewaweb Team, 2018, 1 Desember 2019)

\section{Hasil Penelitian}

3.1 Konfigurasi dan Instalasi

GLPI server dapat dijalankan pada sistem operasi Linux maupun Windows berbasis NT. Komunikasi antara komputer klien dengan manajemen server, GLPI dibuat berbasiskan pada standar HTTP protokol. Server GLPI dapat berjalan di komputer yang menjalankan Apache/MySQL/PHP. (GLPI Project, 2019)

Berikut adalah sistem yang dibutuhkan untuk membangun sebuah server GLPI:

Tabel 3.1 Spesifikasi Sistem Server GLPI

\begin{tabular}{|l|l|}
\hline \multicolumn{1}{|c|}{ Sistem } & \multicolumn{1}{c|}{ Keterangan } \\
\hline Web server & Apache \\
\hline Database Management & MySQL 5.7 \\
\hline PHP & 7.2 \\
\hline Ekstensi PHP yang harus ada & $\begin{array}{l}\text { curl, fileinfo, gd, json, } \\
\text { mbstring, mysqli, session, } \\
\text { zlib, simplexml, xml. }\end{array}$ \\
\hline $\begin{array}{l}\text { Ekstensi PHP tambahan yang } \\
\text { digunakan untuk mengaktifkan fitur } \\
\text { tambahan. }\end{array}$ & $\begin{array}{l}\text { cli, domxml, imap, ldap, } \\
\text { openssl, xmlrpc, APCu }\end{array}$ \\
\hline
\end{tabular}

Server ini dibangun pada sebuah virtual machine dengan menggunakan VirtualBox dengan spesifikasi server sebagai berikut:

Tabel 3.2 Spesifikasi Server VirtualBox GLPI

\begin{tabular}{|l|l|}
\hline \multicolumn{1}{|c|}{ Spesifikasi } & \multicolumn{1}{c|}{ Keterangan } \\
\hline Sistem Operasi & Linux Ubuntu Server 18.04 LTS 64-bit \\
\hline RAM & $1024 \mathrm{MB}$ \\
\hline Kapasitas Hard disk & $24,49 \mathrm{~GB}$ \\
\hline Processor & $\begin{array}{l}\text { Intel }{ }^{\circledR} \text { Core } \\
2.00 \mathrm{GHz}\end{array}$ \\
\hline Network Adapter & Intel PRO/1000 MT Desktop CPU @ \\
\hline
\end{tabular}

Instalasi mysql digunakan untuk membuat database yang nantinya akan digunakan oleh software GLPI.

Berikut adalah tahap pembuatan database GLPI:

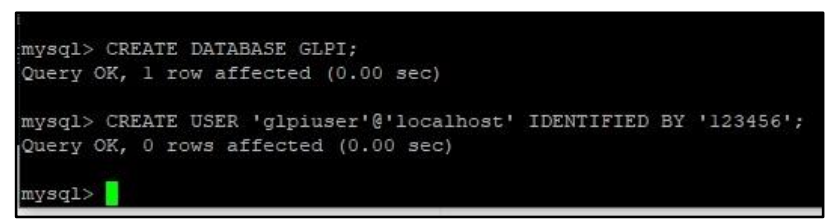

Gambar 3.1 Pembuatan database GLPI

Berikut adalah tahap penggantian hak akses pada database GLPI: 


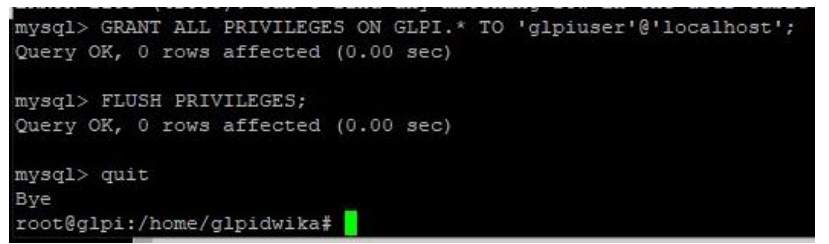

Gambar 3.2 Penggantian hak ases database

Tujuan penggantian hak akses menjadi "GRANT ALL PRIVILEGES" adalah agar dapat memiliki hak untuk semua akses seperti read, write, create, delete database.

Setelah berhasil melakukan konfigurasi server, langkah selanjutnya adalah instalasi software GLPI. Langkah pertama yang dilakukan adalah memasukan IP yang ada pada server pada address bar yang ada di web browser dan diikuti dengan "/glpi/install/install.php" untuk mulai melakukan instalasi. Selanjutnya akan masuk ke bagian awal instalasi yang dapat dilihat pada Gambar 3.3 Pada bagian ini terdapat pengaturan Bahasa. Selanjutnya klik "OK". (Admin, 2019, 19 November 2019)

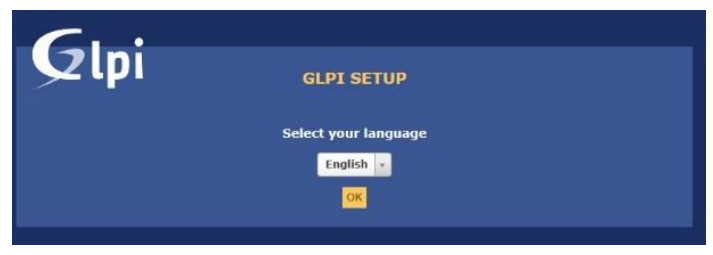

Gambar 3.3 Pengaturan Bahasa pada GLPI Setup

Langkah selanjutnya adalah tahap lisensi. Pilih "I have read and ACCEPT the terms of the license written above" lalu klik "continue". Berikut adalah Gambar 3.4 mengenai tahap lisensi.

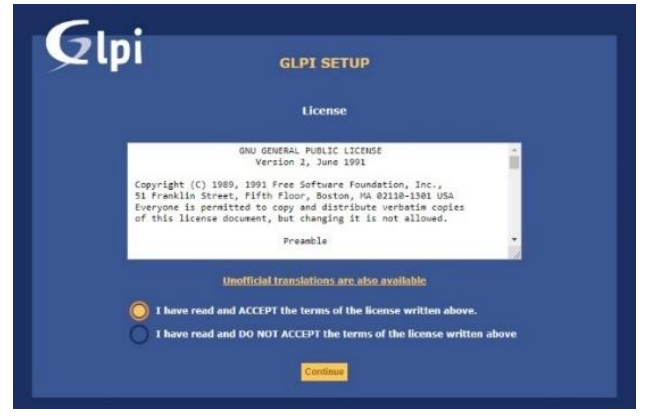

Gambar 3.4 Pengaturan License pada GLPI Setup

Langkah selanjutnya adalah awal instalasi. Terdapat dua pilihan, "Install" untuk melengkapi instalasi GLPI yang baru dan "Upgrade" yang digunakan untuk update versi GLPI ke versi yang baru. Pilih "Install" untuk melanjutkan instalasi.

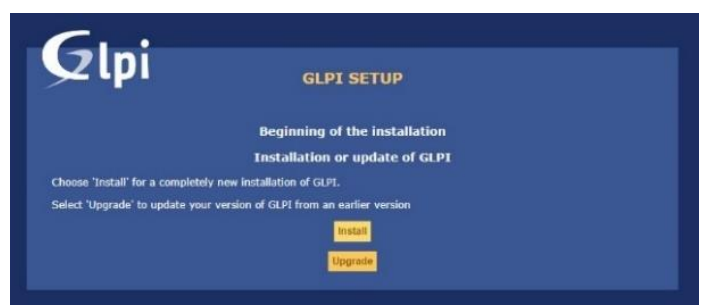

Gambar 3.5 Pengaturan Awal pada GLPI Setup

Langkah selanjutnya adalah pengecekan sistem server atau "environment check" yang telah dibuat. Server GLPI akan berjalan pada komputer dengan spesifikasi yang telah disebutkan di atas pada uraian di atas.

Langkah selanjutnya adalah Database connection setup. Pada langkah ini, terdapat kolom untuk memasukkan SQL server, SQL user dan SQL password yang telah dibuat pada saat konfigurasi server. Hasilnya dapat dilihat pada Gambar 3.6.

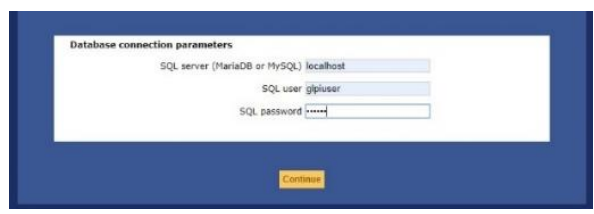

Gambar 3.6 Pengisian Database Connection pada GLPI Setup

Langkah selanjutnya adalah tes koneksi dari database (pemilihan database). Sebelumnya telah dibuat database saat konfigurasi di server bernama "GLPI". Jika pada langkah Database connection setup berhasil memasukkan SQL server, SQL user dan SQL password, maka database yang sebelumnya telah dibuat akan muncul pada langkah ini. Pada langkah ini juga menawarkan untuk membuat database baru jika belum memiliki database. Berikut adalah Gambar 3.7 yang merupakan gambar langkah tes koneksi dari database.

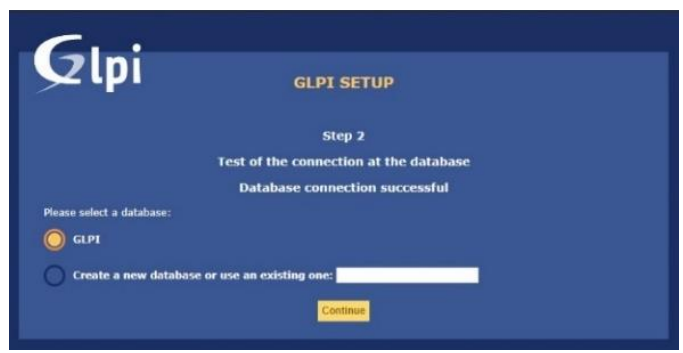

Gambar 3.7 Pemilihan Database pada GLPI Setup Langkah selanjutnya adalah melakukan finishing. Setelah database terinisialisasi, maka GLPI sudah siap digunakan.

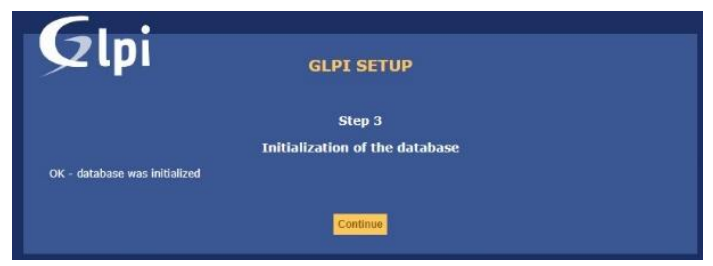

Gambar 3.8 Langkah Terakhir dari GLPI Setup 


\subsection{Fungsionalitas GLPI}

GLPI menyediakan banyak fitur yang dapat digunakan dalam IT Service Management, salah satunya adalah sebagai service desk. Layanan yang disediakan pada service desk diantaranya adalah inventory dan permintaan layanan IT. GLPI merupakan free asset and IT management software, dengan demikian GLPI memberi kebebasan kepada para penggunanya untuk bebas menjalankan, memodifikasi serta mengembangkan sesuai dengan kebutuhan yang membuat fungsi seorang administrator menjadi lebih mudah. Fungsionalitas GLPI yang akan dibahas dibagi menjadi dua bagian besar yaitu user account dan menu Assets dan Assistance yang ada pada GLPI.

GLPI mempunyai 6 menu utama, yaitu Assets, Assitance, Management, Tools, Administration dan Setup. Masingmasing menu mempunyai sub-kategori yang berbeda-beda. Menu Asset dan Assistance mengambil bagian besar dalam pembahasan IT Asset Management dan layanan IT. Berikut adalah penjelasannya:

\section{a. Menu Assistance}

Pada dasarnya menu Assistance adalah gambaran fungsi GLPI sebagai service desk support. User interface GLPI memudahkan penggunanya untuk membuat dan mengelola tiket bantuan. Pengguna biasa dapat membuat tiket baru untuk meminta layanan IT (service desk support). Admin dan teknisi dapat menambahkan tiket secara manual sehingga jika ada pengguna biasa yang meminta bantuan dapat langsung dibuatkan tiket. Admin dan teknisi juga dapat assign tiket pengguna ke teknisi yang sesuai dengan permintaan layanan IT yang diajukan pengguna.

Menu Assistance memiliki sub-kategori yaitu Tracking, Helpdesk, Planning, dan Statistics. Tracking memungkinkan admin untuk melihat daftar semua tiket yang dikirimkan oleh pengguna. Alat pencarian yang ada pada kategori tracking, menawarkan filter pencarian yang sederhana dan canggih untuk mempersempit daftar tiket sesuai dengan kriteria yang diinginkan, mengurutkan daftar tiket dan menampilkan banyak action pada banyak item.

Selain itu daftar tiket yang sudah ada dapat diekspor dengan hasil PDF, Excel, dan format lainnya. Administrator sistem dapat melakukan tindakan pada semua tiket, tetapi pengguna biasa hanya dapat mengakses informasi pada tiket yang dibuat. Sesuai dengan penjelasan user account di atas. Tiket aktif dirangkum untuk pengguna di dalam daftar. Daftar ini mencakup beberapa bidang data, seperti tanggal pembuatan, tanggal pembaruan terakhir, pemohon dan teknisi yang bertanggung jawab atas tiket tersebut. Jika pengguna memilih suatu tiket dalam daftar, maka pengguna dapat melihat, mengedit, atau menutup tiket.

\section{b. Menu Assets}

Menu Assets/Inventory adalah menu yang berfungsi untuk menambahkan aset ke dalam software melalui cara manual. Dalam pengoperasiannya, dapat dibantu dengan plugin OCSInventory-NG. Sehingga dapat update inventory dapat dilakukan secara online dan terjadwal secara otomatis.
User Interface GLPI memudahkan administrator sistem ataupun teknisi dalam menambahkan aset/inventori. Saat memasukin menu Assets, tedapat daftar inventori yang sudah ditambahkan. Untuk menambahkan aset dapat dilakukan dengan cara klik tanda "+" yang ada pada bawah tulisan menu Assets. Lalu akan muncul form yang berisi informasi yang harus diisi saat ingin menambahkan aset.

Daftar aset menampilkan nama, status, manufacturer, type, model, last update dan alternative username yang sebelumnya diisi melalui form saat akan menambahkan aset yang baru. Alat pencarian yang ada pada setiap sub-kategori aset menawarkan filter pencarian yang sederhana dan canggih untuk mempersempit daftar aset sesuai dengan kriteria yang diinginkan, atau dapat langusng diketikan nama aset yang ingin dicari.

Selain itu daftar aset dapat diekspor dengan hasil PDF, Excel dan format lainnya. Administrator sistem dapat melakukan tindakan pada semua aset yang ada, tetapi pengguna biasa hanya dapat mengakses menu Reservations untuk mendapatkan informasi aset mana yang dapat diajukan pinjaman atau sedang available.

\section{c. Menu Reservations}

Menu Reservations erat kaitannya dengan menu Assets, dimana pengguna biasa dapat mengajukan peminjaman suatu aset melalui menu ini. Mekanismenya, administrator sistem mengubah status aset menjadi "Reservable item" agar dapat muncul pada menu Reservations yang ada pada pengguna biasa. Setelah itu pengguna biasa dapat mengajukan peminjaman aset.

\subsection{Pengujian GLPI}

Setelah instalasi berhasil, langkah selanjutnya adalah melakukan testing software untuk memastikan sudah berjalan dengan sebagaimana mestinya. Ada beberapa testing yang telah dilakukan yaitu testing login, pembuatan akun, penambahan aset, pencarian aset, ekspor aset, reservasi aset, pembuatan tiket, pencarian tiket dan ekspor tiket.

\section{a. Login}

Login dapat dilakukan dengan memasukkan username dan password. Berikut adalah tabel skenario pengujian login:

Tabel 3.3 Tabel skenario pengujian login GLPI

\begin{tabular}{|c|c|c|c|c|c|}
\hline $\begin{array}{c}\text { Nama } \\
\text { Pengujian }\end{array}$ & $\begin{array}{l}\text { Deskripsi } \\
\text { Pengujian }\end{array}$ & $\begin{array}{l}\text { Langkah } \\
\text { Pengujian }\end{array}$ & $\begin{array}{c}\text { Keluaran } \\
\text { yang } \\
\text { Diharapkan }\end{array}$ & $\begin{array}{c}\text { Hasil } \\
\text { yang } \\
\text { Didapat }\end{array}$ & Status \\
\hline $\begin{array}{l}\text { Login } \\
\text { GLPI }\end{array}$ & $\begin{array}{l}\text { Pengguna } \\
\text { login GLPI } \\
\text { menggunakan } \\
\text { data yang } \\
\text { benar }\end{array}$ & $\begin{array}{l}\text { 1. masukkan } \\
\text { username: } \\
\text { dwika.nur } \\
\text { (benar) } \\
\text { 2. masukkan } \\
\text { password: } \\
\text { Glpi123456 } \\
\text { (benar) }\end{array}$ & $\begin{array}{l}\text { Masuk ke } \\
\text { halaman } \\
\text { awal GLPI } \\
\text { (Home) }\end{array}$ & $\begin{array}{l}\text { Masuk ke } \\
\text { halaman } \\
\text { awal } \\
\text { GLPI } \\
\text { (Home) }\end{array}$ & Valid \\
\hline $\begin{array}{l}\text { Login } \\
\text { GLPI }\end{array}$ & $\begin{array}{l}\text { Pengguna } \\
\text { login GLPI } \\
\text { menggunakan } \\
\text { data yang } \\
\text { salah }\end{array}$ & $\begin{array}{l}\text { 1. masukkan } \\
\text { username: } \\
\text { dwika.nur } \\
\text { (benar) } \\
\text { 2. masukkan } \\
\text { password: } \\
\text { Glpi1234 } \\
\text { (salah) }\end{array}$ & $\begin{array}{l}\text { Masuk ke } \\
\text { halaman } \\
\text { invalid } \\
\text { access }\end{array}$ & $\begin{array}{l}\text { Masuk ke } \\
\text { halaman } \\
\text { invalid } \\
\text { access }\end{array}$ & Valid \\
\hline
\end{tabular}


b. Pembuatan akun

Semua akun user dibuat oleh administrator sistem. Pembuatan akun user dapat dilakukan oleh user yang mempunyai role sebagai admin dan super-admin seperti yang sudah dijelaskan di atas. Berikut adalah tabel skenario pengujian dari pembuatan akun:

Tabel 3.4 Tabel skenario pengujian pembuatan akun

\begin{tabular}{|c|c|c|c|c|c|}
\hline $\begin{array}{c}\text { Nama } \\
\text { Pengujian }\end{array}$ & $\begin{array}{l}\text { Deskripsi } \\
\text { Pengujian }\end{array}$ & $\begin{array}{c}\text { Langkah } \\
\text { Pengujian }\end{array}$ & $\begin{array}{c}\text { Keluaran } \\
\text { yang } \\
\text { Diharapkan }\end{array}$ & $\begin{array}{c}\text { Hasil yang } \\
\text { Didapat }\end{array}$ & Status \\
\hline $\begin{array}{l}\text { Pembuatan } \\
\text { akun } \\
\text { pengguna }\end{array}$ & $\begin{array}{l}\text { Membuat } \\
\text { akun } \\
\text { pengguna }\end{array}$ & $\begin{array}{l}\text { 1. Pilih menu } \\
\text { Administrati } \\
\text { ons } \\
\text { 2. Pilih sub- } \\
\text { kategori } \\
\text { users } \\
\text { 3. Pilih "Add } \\
\text { User" } \\
\text { 4. Mengisi } \\
\text { form } \\
\text { 5. Pilih "Add" }\end{array}$ & $\begin{array}{l}\text { Pengguna } \\
\text { yang telah } \\
\text { dibuat akan } \\
\text { muncul } \\
\text { pada } \\
\text { halaman } \\
\text { daftar users. }\end{array}$ & $\begin{array}{l}\text { Pengguna } \\
\text { yang telah } \\
\text { dibuat } \\
\text { muncul } \\
\text { pada } \\
\text { halaman } \\
\text { daftar } \\
\text { users. }\end{array}$ & Valid \\
\hline
\end{tabular}

c. Penambahan Aset

Aset yang dapat ditambahkan berupa computer, monitor, software, network, device, printer, cartridge, consumable dan phone seperti yang sudah dijelaskan diatas. Penambahan dapat aset dilakukan dengan dua acara, yaitu dengan menambahkan OCSInventory-NG sebagai plugin dan penambahan secara manual melalui GLPI. OCSInventory agent akan diinstal pada komputer atau laptop client, lalu dengan demikian data dari komputer tersebut seperti spesifikasi dan serial number dapat terbaca secara otomatis di server dari OCSInventory-NG. Sehingga otomatis aset dapat ter-update.

Berikut adalah tabel skenario pengujian penambahan aset pada GLPI:

Tabel 3.5 Tabel skenario pengujian penambahan aset

\begin{tabular}{|c|c|c|c|c|c|}
\hline $\begin{array}{c}\text { Nama } \\
\text { Pengujian }\end{array}$ & $\begin{array}{l}\text { Deskripsi } \\
\text { Pengujian }\end{array}$ & $\begin{array}{c}\text { Langkah } \\
\text { Pengujian }\end{array}$ & $\begin{array}{c}\text { Keluaran } \\
\text { yang } \\
\text { Diharapkan }\end{array}$ & $\begin{array}{l}\text { Hasil yang } \\
\text { Didapat }\end{array}$ & Status \\
\hline $\begin{array}{l}\text { Penambah } \\
\text {-an aset }\end{array}$ & $\begin{array}{l}\text { Penambahan } \\
\text { aset pada } \\
\text { GLPI }\end{array}$ & \begin{tabular}{|l} 
1. Pilih menu \\
Assets \\
2. Pilih sub- \\
kategori \\
aset yang \\
akan \\
ditambah- \\
kan \\
3. Pilih tanda \\
(+) \\
4. Mengisi \\
form \\
5. Pilih "Add"
\end{tabular} & $\begin{array}{l}\text { Aset yang } \\
\text { ditambah- } \\
\text { kan akan } \\
\text { muncul } \\
\text { pada daftar } \\
\text { aset. }\end{array}$ & $\begin{array}{l}\text { Aset yang } \\
\text { ditambah- } \\
\text { kan } \\
\text { muncul } \\
\text { pada daftar } \\
\text { aset. }\end{array}$ & Valid \\
\hline
\end{tabular}

d. Pencarian Aset

Pencarian aset dilakukan dengan cara mengisi kolom yang kosong dengan nama aset, status, atau apapun yang ditampilkan pada kriteria aset.

Berikut adalah tabel skenario pengujian pencarian aset pada halaman daftar aset:
Tabel 3.6 Tabel skenario pengujian pencarian aset pada daftar aset

\begin{tabular}{|c|c|c|c|c|c|}
\hline $\begin{array}{c}\text { Nama } \\
\text { Penguiian }\end{array}$ & $\begin{array}{l}\text { Deskripsi } \\
\text { Penguijan }\end{array}$ & $\begin{array}{l}\text { Langkah } \\
\text { Penguiian }\end{array}$ & $\begin{array}{c}\text { Keluaran } \\
\text { yang } \\
\text { Diharapkan }\end{array}$ & $\begin{array}{c}\text { Hasil yang } \\
\text { Didapat }\end{array}$ & Status \\
\hline $\begin{array}{l}\text { Pencarian } \\
\text { aset }\end{array}$ & $\begin{array}{l}\text { Pencarian } \\
\text { aset dengan } \\
\text { parameter } \\
\text { nama ataut } \\
\text { ienis aset }\end{array}$ & $\begin{array}{l}\text { 1. Pilih menu } \\
\text { Assets } \\
\text { 2. Pilih sub- } \\
\text { kategori } \\
\text { aset yang } \\
\text { ingin dicari } \\
\text { 3. Masukkan } \\
\text { parameter } \\
\text { yang akan } \\
\text { dicari. } \\
\text { Disini } \\
\text { dituliskan } \\
\text { "usb"* } \\
\text { 4. Pilih } \\
\text { "Search" }\end{array}$ & $\begin{array}{l}\text { Aset yang } \\
\text { mempunyai } \\
\text { parameter } \\
\text { tersebut } \\
\text { akan } \\
\text { muncul } \\
\text { pada daftar } \\
\text { aset. }\end{array}$ & $\begin{array}{l}\text { Aset yang } \\
\text { mem- } \\
\text { punyai } \\
\text { parameter } \\
\text { "usb" } \\
\text { muncul } \\
\text { pada daftar } \\
\text { aset. }\end{array}$ & Valid \\
\hline
\end{tabular}

*Dengan catatan kategori parameter dengan isi parameter mempunyai keterkaitan.

\begin{tabular}{|c|c|c|c|c|c|}
\hline $\begin{array}{l}\text { Pencarian } \\
\text { aset }\end{array}$ & $\begin{array}{l}\text { Dencarian } \\
\text { aset dengan } \\
\text { parameter } \\
\text { nama ataut } \\
\text { jenis aset. } \\
\text { Kategori } \\
\text { parameter } \\
\text { denga isi } \\
\text { parameter } \\
\text { tidak ada } \\
\text { keterkaitan }\end{array}$ & $\begin{array}{l}\text { 1. Pilih menu } \\
\text { Assets } \\
\text { 2. Pilih sub- } \\
\text { kategori } \\
\text { aset yang } \\
\text { ingin dicari } \\
\text { 3. Masukkan } \\
\text { parameter } \\
\text { yang akan } \\
\text { dicari. } \\
\text { Disini } \\
\text { dituliskan } \\
\text { "usb"* } \\
\text { 4. Pilih } \\
\text { "Search" }\end{array}$ & $\begin{array}{l}\text { Akan } \\
\text { muncul } \\
\text { halaman } \\
\text { "No item } \\
\text { found" }\end{array}$ & $\begin{array}{l}\text { Muncul } \\
\text { halaman } \\
\text { "No item } \\
\text { found" }\end{array}$ & Valid \\
\hline
\end{tabular}

e. Reservasi Aset

Divisi IKT melayani peminjaman tiap aset IT yang ada, anatar lain kabel HDMI, Flashdisk, LCD Proyektor, kabel LAN dan lain-lain. Setiap staf yang ingin melakukan reservasi atau peminjaman aset dianjurkan untuk mengisi form reservasi yang ada pada GLPI. Semua staf diberikan akun user dengan role Self-service. Aset yang dapat dipinjam akan ditampilkan pada daftar "Reservable Item".

Berikut adalah tabel skenario pengujian reservasi aset:

Tabel 3.7 Tabel skenario pengujian reservasi aset

\begin{tabular}{|c|c|c|c|c|c|}
\hline $\begin{array}{c}\text { Nama } \\
\text { Pengujian }\end{array}$ & $\begin{array}{l}\text { Deskripsi } \\
\text { Penguiian }\end{array}$ & $\begin{array}{l}\text { Langkah } \\
\text { Pengujian }\end{array}$ & $\begin{array}{l}\text { Keluaran } \\
\text { yang } \\
\text { Diharapkan }\end{array}$ & $\begin{array}{c}\text { Hasil yang } \\
\text { Didapat }\end{array}$ & Status \\
\hline $\begin{array}{l}\text { Resserxasi } \\
\text { ataut } \\
\text { pemijaman } \\
\text { aset }\end{array}$ & $\begin{array}{l}\text { Reservasi } \\
\text { ataut } \\
\text { peminjaman } \\
\text { asset oleh } \\
\text { staf. }\end{array}$ & $\begin{array}{l}\text { 1. Pilih menu } \\
\text { Reservation } \\
\text { 2. Pilih aset } \\
\text { yang akan } \\
\text { dipinjam. } \\
\text { 3. Mengisi } \\
\text { form } \\
\text { peminiam- } \\
\text { an } \\
\text { 4. Pilih " } A d d " \text {. }\end{array}$ & $\begin{array}{l}\text { Aset yang } \\
\text { sudah } \\
\text { diresertasasi } \\
\text { akan } \\
\text { muncul } \\
\text { pada } \\
\text { halaman } \\
\text { kalender } \\
\text { yang ada } \\
\text { pada menu } \\
\text { Reservations. }\end{array}$ & $\begin{array}{l}\text { Aset yang } \\
\text { sudah } \\
\text { direservasi } \\
\text { muncul } \\
\text { pada } \\
\text { halaman } \\
\text { kalender } \\
\text { yang ada } \\
\text { pada menu } \\
\text { Reservations }\end{array}$ & Valid \\
\hline
\end{tabular}

f. Pembuatan Tiket

Pembuatan tiket dapat dilakukan oleh siapa saja, dari selfservice user hingga admin. Pembuatan tiket dapat dilakukan 
ketika sedang ada kendala atau masalah dengan layanan IT dan/atau ingin melakukan permintaan layanan IT.

Berikut adalah tabel skenario pengujian pembuatan tiket oleh staf:

Tabel 3.8 Tabel Skenario pengujian pembuatan tiket

\begin{tabular}{|c|c|c|c|c|c|}
\hline $\begin{array}{c}\text { Nama } \\
\text { Pengujian }\end{array}$ & $\begin{array}{l}\text { Deskripsi } \\
\text { Penguiian }\end{array}$ & $\begin{array}{l}\text { Langkah } \\
\text { Pengujian }\end{array}$ & $\begin{array}{c}\text { Keluaran } \\
\text { yang } \\
\text { Diharapkan }\end{array}$ & $\begin{array}{c}\text { Hasil yang } \\
\text { Didapat }\end{array}$ & Status \\
\hline $\begin{array}{l}\text { Pembuatan } \\
\text { tiket pada } \\
\text { GLPI }\end{array}$ & $\begin{array}{l}\text { Dembuatan } \\
\text { tiket pada } \\
\text { GLPI untuk } \\
\text { permintaan } \\
\text { layanan IT. }\end{array}$ & $\begin{array}{l}\text { 1. Pilih menu } \\
\text { Creat a } \\
\text { ticket } \\
\text { 2. Mengisi } \\
\text { formulir } \\
\text { 3. Pilih } \\
\text { "Submit } \\
\text { message" }\end{array}$ & $\begin{array}{l}\text { Tiket yang } \\
\text { sudah } \\
\text { dibuat akan } \\
\text { muncul } \\
\text { pada } \\
\text { halaman } \\
\text { Tickets, baik } \\
\text { yang ada } \\
\text { pada } \\
\text { interface } \\
\text { self-service } \\
\text { maupun } \\
\text { admin }\end{array}$ & $\begin{array}{l}\text { Tiket yang } \\
\text { sudah } \\
\text { dibuat } \\
\text { muncul } \\
\text { pada } \\
\text { halaman } \\
\text { Tickets, } \\
\text { pada } \\
\text { interface } \\
\text { self- } \\
\text { service } \\
\text { dan admin }\end{array}$ & Valid \\
\hline
\end{tabular}

\section{g. Penugasan Tiket}

Tiket akan diterima oleh adiministrator sistem yang selanjutnya akan ditugaskan ke teknisi yang dapat bertanggung jawab dengan tiket tersebut.

Berikut adalah skenario pengujian penugasan tiket dari admin ke teknisi:

Tabel 3.3 Tabel Skenario pengujian penugasan tiket

\begin{tabular}{|c|c|c|c|c|c|}
\hline $\begin{array}{c}\text { Nama } \\
\text { Penguiian }\end{array}$ & $\begin{array}{l}\text { Deskripsi } \\
\text { Penguiian }\end{array}$ & $\begin{array}{l}\text { Langkah } \\
\text { Penguijan }\end{array}$ & $\begin{array}{l}\text { Keluaran } \\
\text { yang } \\
\text { Diharapkan }\end{array}$ & $\begin{array}{c}\text { Hasil yang } \\
\text { Didapat }\end{array}$ & Status \\
\hline $\begin{array}{l}\text { Penugasan } \\
\text { tiket }\end{array}$ & \begin{tabular}{ll}
\multicolumn{2}{l}{ Penugasan } \\
tiket & dari \\
admin & ke \\
teknisi
\end{tabular} & $\begin{array}{l}\text { 1. Pilih menu } \\
\text { Assistance } \\
\text { 2. Pilih sub- } \\
\text { kategori } \\
\text { Tickets } \\
\text { 3. Pilih tiket } \\
\text { yang } \\
\text { diterima } \\
\text { 4. Pilih teknisi } \\
\text { yang akan } \\
\text { ditugaskan } \\
\text { 5. Pilih "Save" }\end{array}$ & $\begin{array}{l}\text { Tiket yang } \\
\text { sudah di- } \\
\text { tugaskan } \\
\text { pada } \\
\text { seorang } \\
\text { teknisi akan } \\
\text { muncul } \\
\text { pada } \\
\text { interface } \\
\text { teknisi } \\
\text { tersebut }\end{array}$ & $\begin{array}{l}\text { Tiket yang } \\
\text { sudah di- } \\
\text { tugaskan } \\
\text { pada } \\
\text { seorang } \\
\text { teknisi } \\
\text { muncul } \\
\text { pada } \\
\text { interface } \\
\text { teknisi } \\
\text { Rafi }\end{array}$ & Valid \\
\hline
\end{tabular}

\section{h. Pencarian Tiket}

Seorang administrator sistem menerima tiket dari staf. Semua tiket dapat dilihat pada sub-kategori tracking. Alat pencarian membantu untuk merangkum tiket dalam suatu parameter status yang telah disediakan seperti yang dijelaskan di atas. Alat pencarian dapat dimodifikasi sesuai dengan kebutuhan pencarian dari pencarian yang sangat luas hingga pencarian yang lebih sempit.

Berikut adalah tabel skenario pengujian pencarian tiket yang ada pada daftar tiket:
Tabel 3.4 Tabel skenario pengujian pencarian tiket pada daftar tiket

\begin{tabular}{|c|c|c|c|c|c|}
\hline $\begin{array}{c}\text { Nama } \\
\text { Penguijan }\end{array}$ & $\begin{array}{l}\text { Deskripsi } \\
\text { Pengujian }\end{array}$ & $\begin{array}{l}\text { Langkah } \\
\text { Penguiian }\end{array}$ & $\begin{array}{c}\text { Keluaran } \\
\text { yang } \\
\text { Diharapkan }\end{array}$ & $\begin{array}{l}\text { Hasil yang } \\
\text { Didapat }\end{array}$ & Status \\
\hline $\begin{array}{l}\text { Pencarian } \\
\text { Tiket }\end{array}$ & $\begin{array}{l}\text { Pencarian } \\
\text { tiket dengan } \\
\text { karakteristik } \\
\text { status tiket }\end{array}$ & $\begin{array}{l}\text { 1. Pilih menu } \\
\text { Assistance } \\
\text { 2. Pilih sub- } \\
\text { kategori } \\
\text { Tickets } \\
\text { 3. Masukkan } \\
\text { status yang } \\
\text { akan dicari. } \\
\text { Disini } \\
\text { dituliskan } \\
\text { "Not } \\
\text { solved" } \\
\text { 4. Rilih } \\
\text { "Search" }\end{array}$ & $\begin{array}{l}\text { Tiket yang } \\
\text { mempunxai } \\
\text { status } \\
\text { tersebut } \\
\text { akan } \\
\text { muncul } \\
\text { pada daftar } \\
\text { tiket }\end{array}$ & $\begin{array}{l}\text { Aset yang } \\
\text { mem- } \\
\text { punvai } \\
\text { status "Not } \\
\text { Solved" } \\
\text { muncul } \\
\text { pada daftar } \\
\text { tiket }\end{array}$ & Valid \\
\hline
\end{tabular}

\section{Penutup}

4.1 Kesimpulan

Berdasarkan kegiatan Praktik Kerja Lapangan yang dilakukan mengenai rancang bangun Inventory IT Asset Management berbasis Local Server untuk optimalisasi layanan IT di PT. XYZ, didapat beberapa kesimpulan sebagai berikut:

a. Dengan adanya fitur service desk pada GLPI, dapat membantu mengurangi penggunaan formulir kertas. Pengguna dapat menggunakan GLPI ini untuk pembuatan permintaan layanan IT.

b. Adanya menu ticket yang mempermudah permintaan layanan IT sehingga data permintaan layanan IT tercatat pada daftar ticket. Hal tersebut mempermudah admin untuk mencari ticket baik yang sudah terselesaikan maupun yang belum terselesaikan sesuai dengan daftar status ticket.

c. Manajemen aset IT digunakan untuk mengelola suatu aset sesuai dengan daur hidup aset. Dengan demikian dapat memperpanjang umur aset sehingga dapat memberi keuntungan bagi perusahaan.

\subsection{Saran}

Adapun beberapa saran yang diberikan dalam rancang bangun Inventory IT Asset Management berbasis Local Server untuk optimalisasi layanan IT di PT. XYZ yaitu:

a. Dalam menangani permintaan layanan IT, kenyataannya teknisi sering lupa mengisi "Time to own" dan "Time to resolve" karena bagian tersebut adalah bagian penting dimana evaluasi kerja teknisi dalam memperbaiki sesuatu dinilai dari waktu yang diperlukan untuk memperbaikinya. Begitu juga dengan pelayanan, semakin cepat suatu pelayanan diberikan, maka semakin bagus penilaiannya.

b. Pengecekan reservasi aset dan konfirmasi dengan pengguna secara rutin sehingga dapat diketahui keberadaan suatu aset. Kasus yang sering terjadi adalah terlupakannya aset yang dipinjam sehingga terkadang aset tersebut hilang.

c. Sebaiknya admin dan teknisi saling melakukan konfirmasi saat akan mengubah status ticket. Hal yang 
sering terjadi adalah admin atau teknisi langsung mengubahnya ke status "solved" saat permintaan layanan IT sedang dalam proses pengerjaan.

\section{DAFTAR PUSTAKA}

Aldwin N., 2019. What is localhost? [Online] Available at: https://www.hostinger.com/tutorials/what-is-localhost [1 Desember 2019]

Anonim, 2019. Cara Membuat GLPI di Ubuntu Server 16.04.3 [Online] Available at: http://desainweb.co.id/2018/01/12/cara-membuat-glpi-di-ubuntuserver-16-04-3/ [19 November 2019]

Bambang T., 2018. MENGELOLA ASET TI. [Online] Available at: https://sis.binus.ac.id/2014/10/06/mengelolaaset-ti/ [1 Desember 2019]

Bella Nemesias, 2018. Apa yang dimaksud dengan Manajemen Layanan Teknologi Informasi atau IT Service Management? [Online] Available at: https://www.dictio.id/t/apa-yang-dimaksud-denganmanajemen-layanan-teknologi-informasi-atau-it-servicemanagement/15025/2 [28 November 2019]

Candra, R., Santi, N., \& Eniyati, S. (2015). Implementasi Statistik dengan Database Mysql. Jurnal Teknologi Informasi DINAMIK, 20(2), 132-139.

Desmira, Sumarto, D., \& Yuliani, R. (2017). Rancang Bangun Mail Server Berbasis Squirrelmail Menggunakan MTA (Mail Transfer Agent) Pada PT. Teras Inti Media. Jurnal Prosisko, 4(ISSN : 2406-773), 55-59.

Dewaweb Team, 2018. Panduan phpMyadmin Untuk Pemula. [Online] Available at: https://www.dewaweb.com/blog/panduan-phpmyadminuntuk-pemula/ [1 Desember 2019]

Joseph Boone, 2019. What Is Localhost and How Can You Use It? [Online] Available at: https://helpdeskgeek.com/networking/what-is-localhostand-how-can-you-use-it/ [1 Desember 2019]

Mubarak, A. (2019). RANCANG BANGUN APLIKASI WEB SEKOLAH MENGGUNAKAN UML ( UNIFIED MODELING LANGUAGE ) DAN BAHASA PEMROGRAMAN PHP ( PHP HYPERTEXT PREPROCESSOR ) BERORIENTASI OBJEK Abdul Mubarak. 03(1), 19-25.

Muhammad Fauzy Ramdhani. (2015). PERANCANGAN DAN IMPLEMENTASI APLIKASI WEBSITE T-SHIRT EWAKO ACREEN PRINTING BERBASISKAN ECOMMERCE (1), 781-788.

Nursikuwagus, A., \& Juliana, T. (2016). Perangkat Lunak Sistem Manajemen Aset Dalam Penanganan Aset It. Simetris: Jurnal Teknik Mesin, Elektro Dan Ilmu
Komputer, $\quad 7(1)$,

111. https://doi.org/10.24176/simet.v7i1.494

Octaviyanti, P., \& Andry, J. F. (2018). Audit Sistem Enterprise Asset Management Menggunakan Framework Cobit 5. Ikraith-Informatika, 2(1), 34-42.

Project, G. (2019). GLPI Installation.

Sidik, A. C., Ramdhani, M., \& Darlis, D. (2015). Implementasi Mini Pc Sebagai Server Media Informasi K3 Di Pt. Telehouse Engineering Bandung. E-Proceeding of Applied Science, 1(3), 2592-2612.

Stephen Mann, 2017. What is ITSM? [Online] Available at: https://itsm.tools/what-is-itsm/ [1 Desember 2019]

Welly Rosadi, 2017. GLPI, Aplikasi Powerfull Untuk Manajemen Aset IT Perusahaan. [Online] Available at: https://tekmagz.tncmediawebsite.co.id/ lunak/open-source/glpi-aplikasi-powerfull-untukmanajemen-aset-it-perusahaan[28 November 2019]

Windley, P. J., \& Ph, D. (2002). Managing IT Assets. System, 1-6. 